\title{
Green Synthesis of Silver Nanoparticle by Plant Extracts to Control Tomato wilt Disease caused by Fusarium oxysporum f. sp. lycopersici
}

\author{
Naeema A. Gomaa, Abdou M. M. Mahdy, Raouf N. Fawzy and Gamal A. Ahmed \\ Plant Pathology Department, Faculty of Agric., Benha University
}

\begin{abstract}
Silver nanoparticles were biosynthesized using three plant extracts i.e., Neem, garlic, and lemongrass. Silver nanoparticles were formed by treating aqueous solution of $\mathrm{AgNO}_{3}$ with plant leaf extracts as reducing agent of $\mathrm{Ag}^{+}$to $\mathrm{AgO}$. The synthesized silver nanoparticles were characterized with transmission electron microscopy (TEM), Dynamic Light Scattering- nano sizer (DLS) and Zeta potential. In vitro, Neem AgNPs at concentration $800 \mu \mathrm{L} / \mathrm{L}$ inhibited completely the mycelium growth and sporulation of Fusarium oxysporum f.sp. lycopersici (FOL). Silver Nanoparticle synthesized by neem extract was the most effective treatments in decreasing disease incidence and severity. Moreover, increased the fresh and dry weight of shoot and root of treated plants. Results revealed that plants treated with silver nanoparticles exhibited an increase in activities of defense enzymes such as peroxidase, polyphenol-oxidase, chitinase, phenylalanine ammonia and phenol contents over the control plants. In this respect, silver nanoparticles synthesized by neem extract also were the best treatment. The present results suggest that silver nanoparticles synthesized by plant extracts had fungicidal activity, and it could be an efficient, safe and affordable alternative to chemical fungicides.
\end{abstract}

Keywords: Biological synthesis, silver nanoparticles, Plant extracts, Fusarium oxysporum, tomato

\section{Introduction}

Tomato (Lycopersicon esculentum Mill.) is an important vegetable crop belongs to the family solanaceae. Recently, in 2019, the production volume of tomatoes in Egypt was approximately 6.8 million metric tons. During the period under review, production of tomatoes in the country followed a declining trend. In 2012, the production of tomatoes was highest at 8.6 million metric tons. On a global scale, the annual production of fresh tomatoes amounts to approximately 180 million tones. In comparison, two times more potatoes and four times more rice are grown around the world (FAO, 2019). Tomato plants are subject to infection by many fungal pathogens (Morsy et al., 2009; Abdel Moneim, 2010). Fusarium wilt disease is among the important diseases that attacking tomatoes. Fusarium oxysporum is a soil borne fungal pathogen that infects plants through roots at all stages of plant growth, causes major economic losses by inducing necrosis and wilting symptoms in many crop plants (Ozbay \& Newman, 2004; El-Khallal, 2007). The pathogen enters through the roots of the plant and proliferates in the vascular tissues leading to breakdown of the water economy of the infected plants (Agrios, 2005). Recently, resistance to fungicides by plant pathogenic fungi has become an important problem (Goffeau, 2008). Development of new mechanisms for disease control is urgently required and the development of nanotechnology can help to control different plant diseases (Bouwmeester et al., 2009). The term "nano" is originated from Greek language meaning extremely small (Rai and Gad 2008). Manufacturing of materials at Nano scale was described by Taniguchi in 1974 who coined the term "Nanotechnology" which is the manipulation, amalgamation, and reduction of matter at nano scale to produce products that possess enhanced 
characteristics such as stronger, lighter, cleaner, definite, and specific (Pradeep 2007). Neem (Azadirachta indica) leaf broth in the extracellular synthesis of pure metallic silver and gold nanoparticles and bimetallic Ag nanoparticles and characterized by Transmission electron microscopy revealed that the silver nanoparticles are adsorbed onto the gold nanoparticles, forming a core-shell structure. The rates of reduction of the metal ions by Neem leaf extract are much faster than those observed by Shanker et al.,2004 in their earlier studies using microorganisms such as fungi, highlighting the possibility that nanoparticle biological synthesis methodologies will achieve rates of synthesis comparable to those of chemical methods. Silver nanoparticles were synthesized by the bio-reduction of silver nitrate solution $(1 \mathrm{mM})$ using water extracts of lemongrass leaves. Synthesis of silver nanoparticles was confirmed by the presence of an absorbance peak at 430-450 $\mathrm{nm}$ in UV-visible spectrum. (Gupta and Ganjewala 2015). Allium sativum (garlic) extract was used as the silver salt reducing agent during nanoparticle synthesis as well as the post-synthesis stabilizing ligands. The silver, nanoparticles was ecofriendly and antioxidant and antibacterial activities (El-Refai $\boldsymbol{e t}$ al., 2018).

\section{Materials and Methods}

\section{Isolation and identification of the causal organism:}

Diseased samples of tomato plants showing Fusarium wilt symptoms were collected from Kafr El-sheikh governorate and subjected to isolation trails. The causal of Fusarium wilt was isolated from stem vascular discoloration diseased plants. The infected tissues were cut into small pieces, surface sterilized with sodium hypochlorite $(0.5 \%)$ for $2-3$ minutes, washed for several times with sterilized distilled water, dried between sterilized filter papers and transferred directly to the PDA medium in plate $9 \mathrm{~cm}$. The PDA plates were incubated at $28 \pm 2{ }^{\circ} \mathrm{C}$ for 7 days (Katan et al., 1991). The fungus was purified by hyphal tip technique (Brown, 1924). The emerged fungal hyphal tips were taken randomly from the peripheral ends of the growing colonies and transferred onto poured PDA plates according to (Nelson $\boldsymbol{e t}$ al., 1983). PDA slants from the fungus were kept in refrigerator at $4^{\circ} \mathrm{C}$ for further experiments.

\section{Laboratory Experiments:}

\subsection{Synthesis of Silver Nanoparticles by plant extracts}

Ten grams of lemongrass leaves (Cymbopogon citratus) and twenty grams of neem leaves (Melia azedarach) were obtained from (Fac. Agric. Moshtohor), then leaves were cut into small pieces, and approximately $6 \mathrm{~g}$ of garlic (Allium sativa L.) was chopped and added. Each plant pieces were transferred into a beaker containing $50 \mathrm{~mL}$ of deionizer water and boiled for one hour at $80^{\circ} \mathrm{C}$ in water bath to prepare an extract. Then, prepared extract was allowed to cool and filtered through Whatman paper No.1 into a clean dry beaker. The filtrate extracts collected in the beaker was used to synthesize silver nanoparticles. $1 \mathrm{mM} \mathrm{AgNO}_{3}$ metal ion was added to each prepared plant extracts and mixed in a $150 \mathrm{~mL}$ conical flask then, incubated for $24 \mathrm{~h}$ at room temperature. Periodically, the color change was observed indicating the formation of AgNPs. The solution was further analyzed by DLS, Zeta potential and TEM (Shankar et al., 2004). 


\subsection{Effect of Silver Nanoparticles (AgNPs) synthesized by plant extract on the linear growth and spores' production of Fusarium oxysporum in vitro:}

This study was designed to investigate the inhibitory effect of three AgNPs synthesized by plant extract method, on the linear growth of FOL in vitro. The AgNPs used were tested at 6 concentrations as follows:

1) Neem Ag NPs concentrations $25,50,100,200,400$ and $800 \mu \mathrm{L} / \mathrm{L}$

2) Neem without Ag NPs at concentrations $25,50,100,200,400$ and $800 \mu \mathrm{L} / \mathrm{L}$

3) Lemongrass Ag NPs at concentrations 25, 50, 100,200,400 and $800 \mu \mathrm{L} / \mathrm{L}$

4) Lemon grass without Ag NPs at concentrations $25,50,100,200,400$ and $800 \mu \mathrm{L} / \mathrm{L}$

5) Garlic Ag NPs at concentrations $25,50,100,200,400$ and $800 \mu \mathrm{L} / \mathrm{L}$

6) Garlic without Ag NPs at concentrations 25, 50, 100,200,400 and $800 \mu \mathrm{L} / \mathrm{L}$

The effect of Ag NPs against the tested virulent Fusarium oxysporum f.sp. lycopersici (FOL). isolate was done in vitro. In this respect, The Ag NPs added immediately to the warmed $100 \mathrm{~mL}$ PDA medium. PDA medium in each conical flasks was gently shacked then poured with constant volume $(15 \mathrm{~mL})$ into sterilized Petri dishes $(9 \mathrm{~cm} \emptyset)$ and left to solidify. The medium without Ag NPs served as control. Mycelium discs $(5 \mathrm{~mm} \varnothing)$ from the edge of 7 days old cultures of fungus placed in the center of Petri dishes. Three plates were used for each concentration. Plates were incubated in an incubator at $27^{\circ} \mathrm{C}$. The experiment was terminated when mycelium covered the medium surface in control treatment. Fungal growth was measured by averaging the two diameters taken at right angles for each colony.

\section{Greenhouse Experiments:}

Loamy sand soil [3clay:1sand w/w] was sterilized by thoroughly mixing with 5\% commercial formalin solution (one $\mathrm{L}$ of $5 \%$ formalin solution/cubic feet of soil mixture) and covered with polyethylene for 2 weeks. Later, polyethylene cover was removed, and soil was raked for 10 days for ventilation and formalin evaporation. Similarly, plastic pots $(\$ 20 \mathrm{~cm})$ were sterilized by dipping in 5.0\% commercial formalin solution for 15 minutes, left to dry for 24 hrs. Then filled with the previously sterilized soil. The inoculum of $F$. oxysporum lycopersici (FOL) isolate was grown on PDA plates for 10 days at $27 \pm 2^{\circ} \mathrm{C}$ Then transferred to sterilized sand barley medium for two weeks. Inoculum of FOL was added to the potted soil at rate of $3.0 \% \mathrm{w} / \mathrm{w}$, mixed thoroughly with the soil surface of each pot then watered and left for one week to ensure the distribution of inoculum.

\subsection{Effect of AgNPs synthesized by plant extract as dipping treatment on controlling fusarium wilt:}

In this study, three AgNPs synthesized by plant extract and three plant extract without silver nitrate were evaluated as dipping treatments for controlling fusarium wilt of tomato under greenhouse conditions. The tested treatments were:
A. Neem Ag NPs concentrations 125, 250 and $500 \mu \mathrm{L} / \mathrm{L}$
B. Neem without Ag NPs at concentrations of 125,250 and $500 \mu \mathrm{L} / \mathrm{L}$
C. Lemon grass Ag NPs at concentrations 125, 250 and $500 \mu \mathrm{L} / \mathrm{L}$
D. Lemon grass without Ag NPs at concentrations 125, 250 and $500 \mu \mathrm{L} / \mathrm{L}$
E. Garlic Ag NPs at concentrations 125, 250 and $500 \mu \mathrm{L} / \mathrm{L}$
F. Garlic without Ag NPs at concentrations 125, 250 and $500 \mu \mathrm{L} / \mathrm{L}$

Healthy tomato transplants of Super Strain B 20 days old (from Qaha nurseries, ElQalubia) were dipped in each treatment for $2 \mathrm{~h}$. Then raised and left to dry in air before planting. 
Transplants dipped in water as control. Three transplants per pot and three pots were used as replicates for each treatment. Wilt disease incidence \% (WDI \%) and severity \% (WDS \%) were determined and calculated 60 day post transplanting based on 0-4 scale as described by (Song $\boldsymbol{e t}$ al., 2004), where: $0=$ No infection, $1=$ Slight infection which is about $25 \%$ of full scale: one or two yellowed leaves, $2=$ Moderate infection: two or three yellowed leaves, $50 \%$ of wilted leaves, $3=$ Extensive infection: the all plant leaves became yellow, $75 \%$ of wilted leaves and growth was inhibited and $4=$ Complete infection: the whole plant leaves became yellow, $100 \%$ of wilted leaves, and the plant was died.

Disease severity was calculated as follows:

$\%$ Disease severity $=\Sigma(\mathrm{a} \times \mathrm{b}) / \mathrm{N} \times \mathrm{K} \times 100$,

Where: $\mathrm{a}=$ number of infected plants in each category, $\mathrm{b}=$ numerical value of his category, $\mathrm{N}=$ Total number of examined plant and $\mathrm{K}=$ the highest degree of infection category

Also, disease incidence was also recorded for each individual treatment by the equation:

$\%$ Disease incidence $=\frac{\text { number of infected plants }}{\text { total number of plants }} \times 100$

\section{Data collection:}

The plants were gently removed from pots, washed with tap water, left to air drying at room conditions for about 30-60 minutes then the following parameters i.e., fresh weight and dry of root and shoot as $\mathrm{g} /$ pot were determined then dry biomasses of roots and shoots were determined after oven drying of samples at $65-70^{\circ} \mathrm{C}$ for $2-3$ days until constant weight gained.

\section{Determining of enzyme activities:}

Leaves sample of tomato plants cv. cv. Super strain B that treated with different treatments under study in greenhouse were taken 40 days after transplanting. Leaf samples were ground with $0.2 \mathrm{M}$ Tris $\mathrm{HCl}$ buffer ( $\mathrm{pH} 7.8$ ) containing $14 \mathrm{mM} \beta$-mercaptoethanol at the rate $1 / 3 \mathrm{w} / \mathrm{v}$. The extracts were centrifuged at $10,000 \mathrm{rpm}$ for $20 \mathrm{~min}$ at $4^{\circ} \mathrm{C}$. The supernatant layer was used to determine enzyme activities (Tuzun et al., 1989).

\subsection{Determination of Peroxidase (PO):}

Peroxidase activity was determined according to the method described by Allam and Hollis (1972).

\subsection{Determination of Polyphenoloxidase (PPO):}

The polyphenoloxidase activity was determined according to the method described by Matta and Dimond (1963).

\subsection{Determination of phenylalanine ammonia lyase (PAL):}

The activity of PAL was determined according to the method described by Dickerson $\boldsymbol{e t}$ al., (1984).

\subsection{Determination of chitinase.}

Determination of the activity of chitinase was carried out according to the method of Boller and Mauch, (1988).

\section{Determination of phenolic compounds:}


Phenol contents was determined using Spectrophotometer (SPECTRONIC 20-D) at $520 \mathrm{~nm}$ according to the method of (Bary and Thorpe, 1954).

\section{Results and Discussion}

This part mainly focused on biosynthesis of silver nanoparticles (AgNPs) using plant extract method recovered in the present study.

\section{Synthesis of silver nanoparticles by plant extract}

Neem, Garlic and Lemongrass extracts were successfully synthesized AgNPs. The synthesis of AgNPs was preliminary confirmed by observing the color change of AgNO3 solution after challenging with the plant extract. The color mixture of AgNO3 and the aqueous extract of each plant extracts mentioned above changed rapidly to broad range of brown color, whereas AgNO3 solution without plant extract showed no color change (Fig. 1,2.3). This suggested that AgNPs can be synthesized using plant extract of Neem, Garlic and Lemongrass. It is well known that silver nanoparticles exhibit yellowish brown color in aqueous solution due to excitation of surface plasmon vibrations in silver nanoparticles (Shankar et al., 2004).

\begin{tabular}{|l|l|l|}
\hline \multicolumn{1}{|c|}{$\mid$} & \\
A
\end{tabular}

\section{Characterization of AgNPs}

The average size (Dynamic Light Scattering nano sizer (DLS)) distribution of the AgNPs was $31.3 \mathrm{~nm}$ for Neem, $61.2 \mathrm{~nm}$ for Garlic while Lemongrass was $77.2 \mathrm{~nm}$ (Fig. 5). The negative zeta potential of about $-2.74 \mathrm{mv},-2.85 \mathrm{mv}$ and $-3.16 \mathrm{mv}$ observed for AgNPs biosynthesized from Neem, Garlic and Lemongrass, respectively (Fig. 5). The values strongly supported long time stability of AgNPs (AgNPs are stable up to three months without agglomeration). The estimation of zeta potential is based on the direction of velocity of particles under the influence of known electric field (Gengan $\boldsymbol{e t}$ al., 2013). The results indicate an ideal surface charge of the formed AgNPs. Moreover, the high absolute and negative value of zeta potential revealed a high electrical charge on the AgNPs surface, which can cause a strong repulsive force among the particles to prevent agglomeration and hence might be responsible for their high stability.

The size and morphology of all biosynthesized AgNPs were examined using HR-TEM. The results showed the formation of spherical and well dispersed AgNPs (Fig. 6). 
ISSN 2537_0715

IJSRSD (2021): Volume 4, Issue 3, December 2021

Received: November 2021, Accepted: December 2021

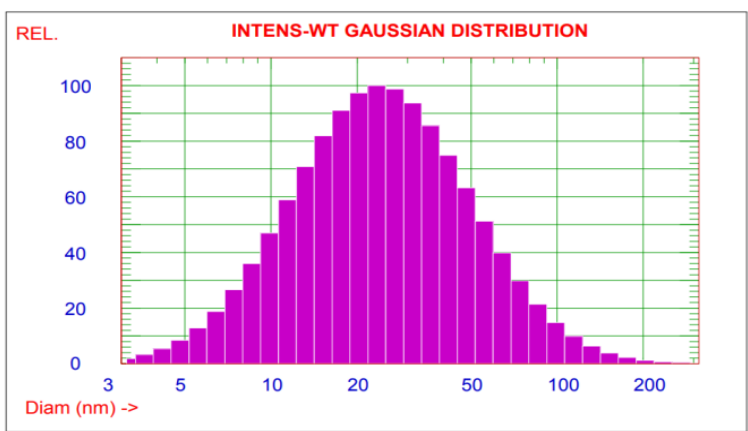

(F1)

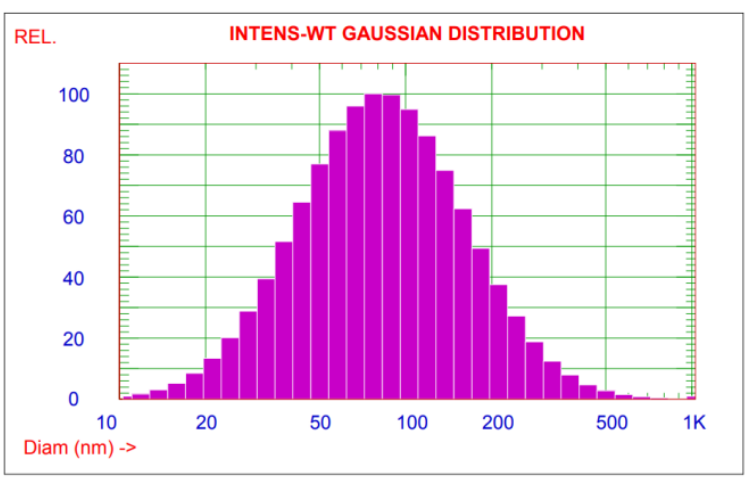

(F2)

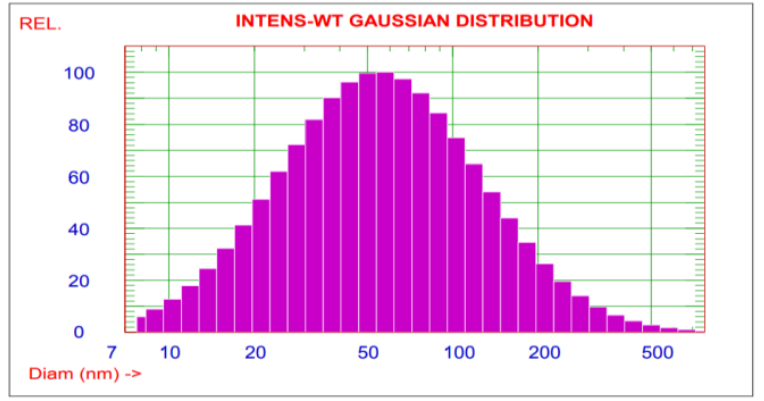

(F3)
International Journal of Scientific Research and Sustainable Development

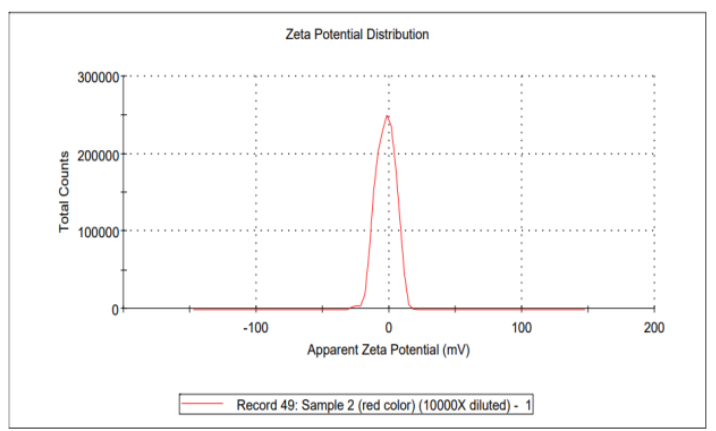

(F1)

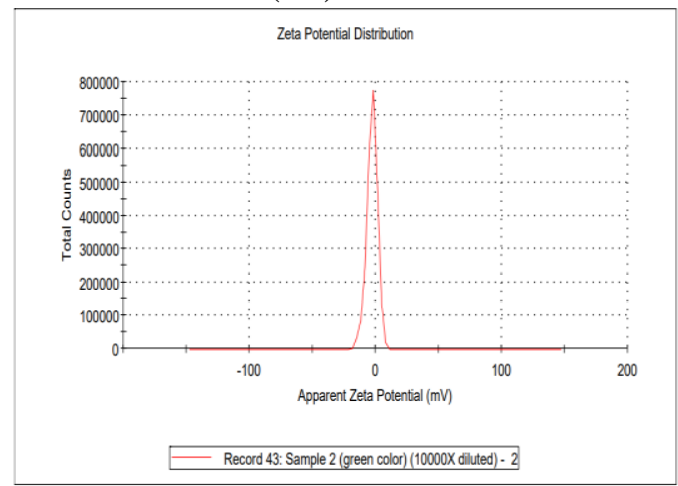

(F2)

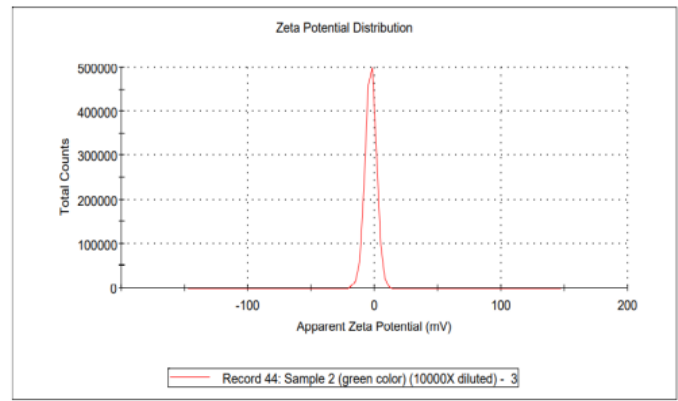

(F3)

Fig. 5: F1-F3: Characterization of the biosynthesized AgNPs by the 3 plant extracts respectively: (Left F1-F3) Particle size distribution analysis, (Right F1-F3) Zeta potential measurements of the bio-synthesized AgNPs

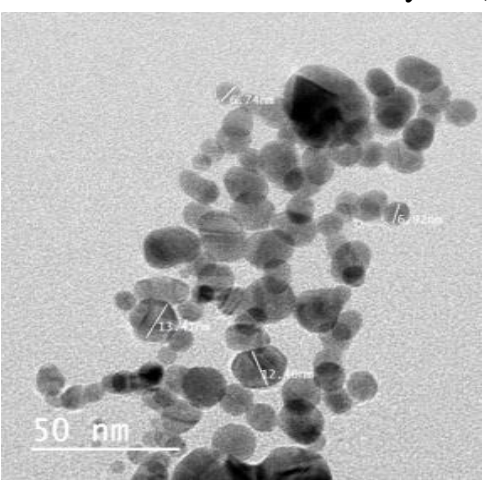

(F1)

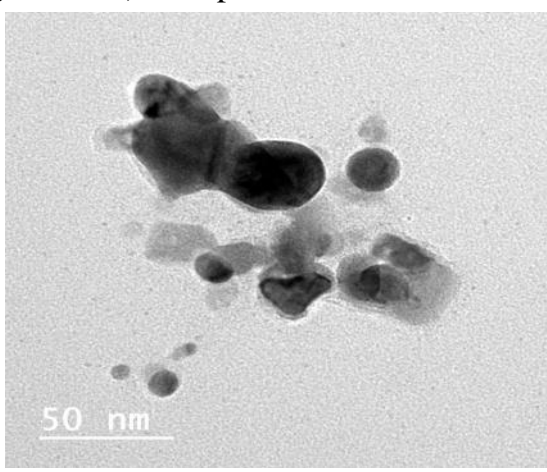

(F2)

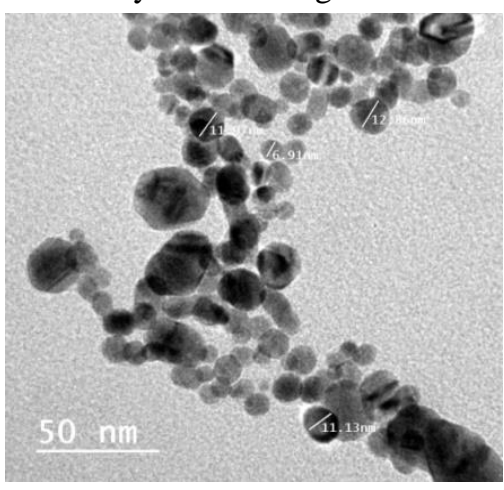

(F3)

Fig.6:F1-F3: HR-TEM images of the biosynthesized AgNPs by the 3 plant extract: (F1 Neem, (F2) Garlic (F3) Lemongrass. 


\section{Effect of silver nanoparticles synthesized by plant extract on the growth and spores' production of $F$. oxysporum in vitro:}

Data in Table 1 and Fig.7, show that, all tested Ag NPs synthesized by plant extract reduced the growth and spores' production of $F$. oxysporum f. sp. lycopersici (FOL) compared with control. Reduction in linear growth and spores' production was increased by increasing concentration of most tested treatments. Neem AgNPs at concentration $800 \mu \mathrm{L} / \mathrm{L}$ inhibited completely the mycelium growth and sporulation of FOL followed by Garlic Ag NPs at concentration $800 \mu \mathrm{L} / \mathrm{L}$ at $85.77 \%$ and spores' production of (FOL) by $91.30 \%$. On the other hand, Lemongrass AgNPs at concentration of $800 \mu \mathrm{L} / \mathrm{L}$ showed the lowest effect which recorded $65.22 \%$ and spores' production by $86.95 \%$. These results agree with those of Elamawi and AlHarbi 2014. They found that, silver nanoparticles with size 1-20 nm at a concentration of 0.5 $\mathrm{mM}$ was effective against Fusarium oxysporum and displayed $68.2 \%$ inhibition of colony formation comparing with the control. Matei et al., (2018) found that, the bioactivity against $F$. culmorum of the different treatments, without and with AgNPs, was studied in vitro by monitoring the radial growth of the mycelium at a concentration of $62.5 \mu \mathrm{g} \cdot \mathrm{mL}-1,125$ $\mu \mathrm{g} \cdot \mathrm{mL}-1,250 \mu \mathrm{g} \cdot \mathrm{mL}-1,500 \mu \mathrm{g} \cdot \mathrm{mL}-1$. These results agree with those of Asharf et al., (2020) they found that efficient inhibition of $F$. oxysporum, the causal agent of tomato wilt, was achieved after exposure to Melia leaf extract (MLE)-AgNPs in vitro and fungal mycelium growth was inhibited with $79-98 \%$ as compared to the control.

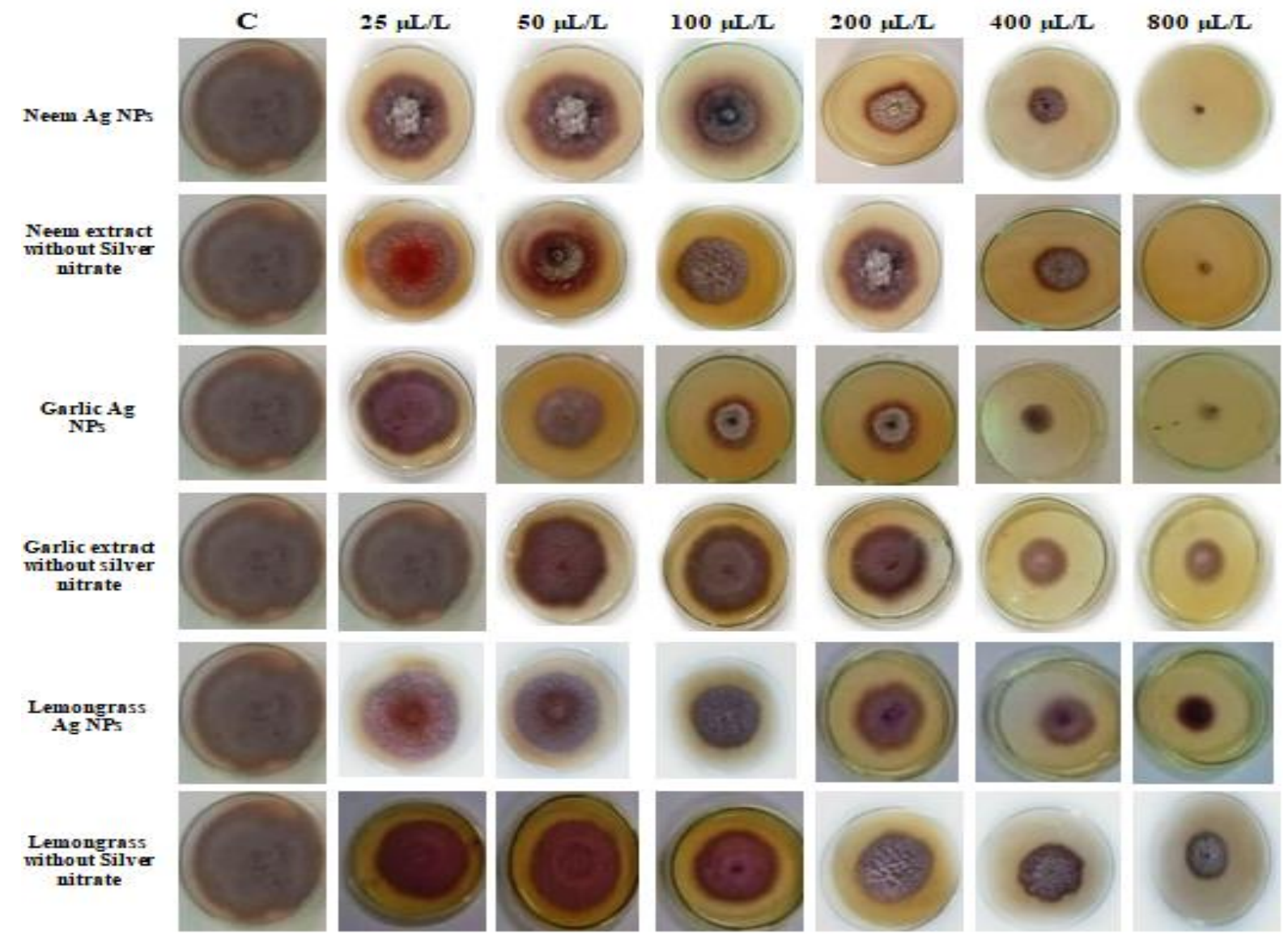

Fig.7: Effect of silver nanoparticles synthesized by plant extract compared plant extract only with on the growth of F. oxysporum in vitro. 
Table 1: Effect of silver nanoparticles synthesized by plant extract on the growth and spores' production of $F$. oxysporum in vitro:

\begin{tabular}{|c|c|c|c|c|c|}
\hline \multirow[t]{2}{*}{ Treatment } & \multirow[b]{2}{*}{$\begin{array}{l}\text { Conc. } \\
\mu \mathrm{L} / \mathrm{L}\end{array}$} & \multirow{2}{*}{$\begin{array}{l}\text { Mycelium } \\
\text { growth }\end{array}$} & \multirow{2}{*}{$\begin{array}{l}\text { No. of spores } \\
\left(* 10^{4}\right) / \mathrm{mL}\end{array}$} & \multicolumn{2}{|c|}{ Efficacy } \\
\hline & & & & $\begin{array}{c}\text { Mycelium } \\
\text { growth }\end{array}$ & $\begin{array}{l}\text { No. of spores } \\
\left(* 10^{4}\right) / \mathrm{mL}\end{array}$ \\
\hline \multirow[t]{6}{*}{ Neem Ag NPs } & 25 & 8.08 & 176 & 10.22 & 52.17 \\
\hline & 50 & 7.11 & 152 & 21 & 58.69 \\
\hline & 100 & 5.41 & 104 & 39.88 & 71.73 \\
\hline & 200 & 3.70 & 100 & 58.88 & 72.82 \\
\hline & 400 & 2.20 & 56 & 75.55 & 84.78 \\
\hline & 800 & 0.00 & 0 & 100.00 & 100.00 \\
\hline \multirow{6}{*}{$\begin{array}{l}\text { Neem extract without } \\
\text { silver nitrate }\end{array}$} & 25 & 8.16 & 184 & 9.88 & 50.00 \\
\hline & 50 & 7.15 & 144 & 20.55 & 60.86 \\
\hline & 100 & 6.06 & 104 & 32.66 & 71.73 \\
\hline & 200 & 4.28 & 80 & 47.55 & 78.26 \\
\hline & 400 & 2.98 & 72 & 66.88 & 80.43 \\
\hline & 800 & 1.20 & 56 & 86.66 & 84.78 \\
\hline \multirow[t]{6}{*}{ Garlic Ag NPs } & 25 & 7.33 & 136 & 18.55 & 63.04 \\
\hline & 50 & 6.41 & 128 & 28.77 & 65.21 \\
\hline & 100 & 5.33 & 104 & 40.77 & 71.73 \\
\hline & 200 & 3.86 & 64 & 57.11 & 82.60 \\
\hline & 400 & 2.76 & 56 & 69.33 & 84.78 \\
\hline & 800 & 1.28 & 32 & 85.77 & 91.30 \\
\hline \multirow{6}{*}{$\begin{array}{l}\text { Garlic extract without } \\
\text { silver nitrate }\end{array}$} & 25 & 7.63 & 168 & 15.22 & 54.34 \\
\hline & 50 & 7.33 & 152 & 18.55 & 58.69 \\
\hline & 100 & 6.92 & 128 & 23.11 & 65.21 \\
\hline & 200 & 6.14 & 80 & 31.77 & 78.26 \\
\hline & 400 & 3.91 & 72 & 56.55 & 80.43 \\
\hline & 800 & 3.18 & 64 & 64.66 & 82.60 \\
\hline \multirow{6}{*}{ Lemongrass AgNPs } & 25 & 6.20 & 144 & 31.11 & 60.86 \\
\hline & 50 & 5.63 & 112 & 37.44 & 69.56 \\
\hline & 100 & 4.58 & 88 & 49.11 & 76.08 \\
\hline & 200 & 4.32 & 72 & 52 & 80.43 \\
\hline & 400 & 3.48 & 64 & 61.33 & 82.60 \\
\hline & 800 & 3.13 & 48 & 65.22 & 86.95 \\
\hline \multirow{6}{*}{$\begin{array}{l}\text { Lemongrass without } \\
\text { silver nitrate }\end{array}$} & 25 & 7.65 & 232 & 17.65 & 36.95 \\
\hline & 50 & 6.68 & 188 & 25.77 & 48.91 \\
\hline & 100 & 6.33 & 168 & 29.66 & 54.34 \\
\hline & 200 & 5.57 & 160 & 38.11 & 56.52 \\
\hline & 400 & 3.77 & 149 & 58.11 & 56.79 \\
\hline & 800 & 3.43 & 130 & 61.88 & 64.67 \\
\hline Control & & 9.00 & 368 & 0.00 & 0.00 \\
\hline LSD at 0.05 & & 0.76 & 17.98 & & \\
\hline
\end{tabular}

Greenhouse experiments:

Effect of AgNPs synthesised by plant extract method as dipping treatment on controlling Fusarium wilt disease on tomato (cv. Super strain B) under greenhouse:

Data in Table 2 show that, all AgNPs synthesized by plant extract reduced significantly 
wilt disease incidence and disease severity, as well as increased fresh and dry weight of shoots and roots of tomato plants compared with the control. In this respect, the highest reduction percentages of disease incidence and disease severity were recorded with Neem Ag NPs 500 $\mu \mathrm{L} / \mathrm{L}$ and maxim-XL which recorded 11.11 of disease incidence and $5.55 \%$ to Neem AgNPs and $11.08 \%$ to maxim-XL of disease severity followed by Garlic Ag NPs $500 \mu \mathrm{L} / \mathrm{L}$. On the other hand, Garlic extract without silver nitrate $125 \mu \mathrm{L} / \mathrm{L}$ was the lowest effective one where it reduced disease incidence and disease severity by 77.78 and $30.56 \%$, respectively. Moreover, the highest increase in fresh and dry weight of shoots and roots was recorded with Neem Ag NPs $500 \mu \mathrm{L} / \mathrm{L}$ treatment followed by garlic Ag NPs $500 \mu \mathrm{g} / \mathrm{L}$. On the other hand, lemon grass was the least effective treatment in this respect. These results are in harmony with those obtained by Madbouly et al., 2017. They found that AgNPs causes reduction in the severity of wilt disease of tomato in the greenhouse by $90 \%$. This was detected through reducing the number of wilted seedlings especially after placing their roots in a suspension of $500 \mathrm{mg} / \mathrm{L}$ of AgNPs for $4 \mathrm{~h}$ prior to infestation of soil with pathogenic $F$. oxysporum, compared with soil treated with the pathogen only.

Table 2: Effect of AgNPs synthesised by plant extract method as dipping treatment on controlling Fusarium wilt disease on tomato (cv. super strain B) under greenhouse:

\begin{tabular}{|c|c|c|c|c|c|c|}
\hline \multirow{2}{*}{ Treatment } & \multirow{2}{*}{ DI\% } & \multirow{2}{*}{ DS\% } & \multicolumn{2}{|c|}{ FW $(g)$} & \multicolumn{2}{|c|}{ DW $(g)$} \\
\hline & & & Shoot & Root & Shoot & Root \\
\hline Neem Ag NPs $125 \mu \mathrm{L} / \mathrm{L}$ & 55.55 & 13.88 & 16.30 & 6.39 & 5.68 & 1.83 \\
\hline Neem Ag NPs $250 \mu \mathrm{L} / \mathrm{L}$ & 33.33 & 11.08 & 18.41 & 7.33 & 5.62 & 1.77 \\
\hline Neem Ag NPs $500 \mu \mathrm{L} / \mathrm{L}$ & 11.11 & 5.55 & 20.08 & 9.52 & 8.48 & 2.18 \\
\hline Neem without silver nitrate125 $\mu \mathrm{L} / \mathrm{L}$ & 66.67 & 19.44 & 12.47 & 4.19 & 3.05 & 1.64 \\
\hline Neem without silver nitrate $250 \mu \mathrm{L} / \mathrm{L}$ & 44.45 & 22.22 & 13.40 & 4.40 & 3.96 & 1.52 \\
\hline Neem without silver nitrate500 $\mu \mathrm{L} / \mathrm{L}$ & 33.33 & 19.44 & 13.24 & 3.64 & 3.64 & 1.38 \\
\hline Garlic Ag NPs $125 \mu \mathrm{L} / \mathrm{L}$ & 55.56 & 27.78 & 14.47 & 4.21 & 5.67 & 1.74 \\
\hline Garlic Ag NPs $250 \mu \mathrm{L} / \mathrm{L}$ & 44.45 & 11.08 & 16.44 & 4.21 & 4.96 & 1.39 \\
\hline Garlic Ag NPs $500 \mu \mathrm{L} / \mathrm{L}$ & 33.33 & 11.08 & 15.80 & 3.90 & 5.59 & 1.68 \\
\hline Garlic extract without silver nitrate125 $\mu \mathrm{L} / \mathrm{L}$ & 77.78 & 30.56 & 12.64 & 3.19 & 4.32 & 1.14 \\
\hline Garlic extract without silver nitrate $250 \mu \mathrm{L} / \mathrm{L}$ & 55.56 & 22.22 & 11.60 & 2.84 & 3.85 & 1.52 \\
\hline Garlic extract without silver nitrate500 $\mu \mathrm{L} / \mathrm{L}$ & 33.33 & 19.44 & 14.78 & 2.51 & 4.09 & 1.60 \\
\hline Lemongrass Ag NPs $125 \mu \mathrm{L} / \mathrm{L}$ & 66.67 & 27.78 & 15.60 & 3.69 & 6.45 & 2.10 \\
\hline Lemongrass Ag NPs $250 \mu \mathrm{L} / \mathrm{L}$ & .3333 & 16.67 & 17.34 & 3.72 & 5.75 & 1.72 \\
\hline Lemongrass Ag NPs $500 \mu \mathrm{L} / \mathrm{L}$ & 22.22 & 13.89 & 17.96 & 4.96 & 5.57 & 1.54 \\
\hline Lemongrass without silver nitrate125 $\mu \mathrm{L} / \mathrm{L}$ & 77.78 & 27.78 & 13.85 & 2.95 & 4.27 & 1.63 \\
\hline Lemongrass without silver nitrate $250 \mu \mathrm{L} / \mathrm{L}$ & 55.56 & 19.44 & 15.84 & 3.41 & 4.14 & 1.83 \\
\hline Lemongrass without silver nitrate500 $\mu \mathrm{L} / \mathrm{L}$ & 33.33 & 16.67 & 9.60 & 2.18 & 3.87 & 1.69 \\
\hline Maxim-XL & 11.11 & 11.08 & 22.73 & 10.05 & 8.60 & 2.42 \\
\hline Bio-Zeid & 22.22 & 13.88 & 18.89 & 8.62 & 7.56 & 2.19 \\
\hline Control 1 & 0.00 & 0.00 & 10.85 & 2.07 & 2.51 & 1.24 \\
\hline Control 2 & 100 & 80.55 & 5.44 & 1.62 & 1.36 & 0.70 \\
\hline LSD at 0.05 & 10.19 & 8.95 & 1.73 & 2.01 & 1.52 & 0.47 \\
\hline
\end{tabular}

DI= disease incidence, $\mathbf{D S}=$ disease severity, $\mathbf{F W}=$ Fresh weight, $\mathbf{D W}=$ Dry weight, Control 1=Un-inoculated soil, Control 2= inoculated soil with FOL. 
Effect of some tested AgNPs synthesised by plant extract method on activities of defenserelated enzyme in tomato plants infected with wilt pathogen under greenhouse:

Data in Table 3 reveal that, all tested treatments significantly increased the activities of peroxidase (PO), polyphenol oxidase (PPO), Phenylalanine ammonia lyase (PAL) and chitinase enzymes compared with control treatment (FOL). Neem Ag NPs $250 \mu \mathrm{L} / \mathrm{L}$ was the best Ag NPs treatment where it increased the activities of PO, PPO, PAL and chitinase enzymes by 2228.5, 913.96, 1063.06 and 1972.72 \%, respectively followed by Maxim-XL. However, Lemongrass without silver nitrate $125 \mu \mathrm{L} / \mathrm{L}$ was the least affective treatment. These results are in harmony with the results of Karim et al., 2012 who found that, low concentrations of novel nanoparticles (silver and gold) increased the activity of plant peroxidases. Ashraf et al., (2020). treating tomato plants with MLE-AgNPs increase the phenolic contents and activities of PO, PPO, and PAL enzymes compare with control.

Table 3: Effect of some tested AgNPs synthesised by plant extract method on activities of defines-related enzyme in tomato plants infected with wilt pathogen under greenhouse:

\begin{tabular}{|c|c|c|c|c|c|c|c|c|}
\hline \multirow{2}{*}{ Treatment } & \multirow{2}{*}{ PO } & \multirow{2}{*}{ PPO } & \multirow{2}{*}{ PAL } & \multirow{2}{*}{ Chitinase } & \multicolumn{4}{|c|}{ Efficacy \% } \\
\hline & & & & & PO & PPO & PAL & Chitinase \\
\hline Neem Ag NPs $125 \mu \mathrm{L} / \mathrm{L}$ & 34.68 & 28.95 & 13.24 & 16.68 & 1575.36 & 819.04 & 496.39 & 910.91 \\
\hline Neem Ag NPs $250 \mu \mathrm{L} / \mathrm{L}$ & 48.20 & 31.94 & 25.82 & 34.20 & 2228.50 & 913.96 & 1063.06 & 1972.73 \\
\hline Neem Ag NPs $500 \mu \mathrm{L} / \mathrm{L}$ & 36.62 & 24.49 & 25.40 & 26.70 & 1669.08 & 677.40 & 1044.14 & 1518.18 \\
\hline Neem without silver nitrate $125 \mu \mathrm{L} / \mathrm{L}$ & 13.14 & 22.78 & 8.64 & 6.30 & 1107.00 & 623.17 & 289.18 & 116.36 \\
\hline Neem without silver nitrate $250 \mu \mathrm{L} / \mathrm{L}$ & 17.91 & 22.56 & 9.89 & 4.92 & 765.21 & 616.19 & 345.49 & 198.18 \\
\hline Neem without silver nitrate $500 \mu \mathrm{L} / \mathrm{L}$ & 29.97 & 23.79 & 9.8 & 5.34 & 1347.82 & 655.23 & 341.44 & 223.64 \\
\hline Garlic Ag NPs $125 \mu \mathrm{L} / \mathrm{L}$ & 30.53 & 24.28 & 8.18 & 10.08 & 1374.89 & 670.79 & 268.46 & 510.91 \\
\hline Garlic Ag NPs $250 \mu \mathrm{L} / \mathrm{L}$ & 41.04 & 27.44 & 11.78 & 17.82 & 1882.6 & 771.11 & 430.63 & 980.00 \\
\hline Garlic Ag NPs $500 \mu \mathrm{L} / \mathrm{L}$ & 35.46 & 28.78 & 25.16 & 17.76 & 1613.04 & 813.65 & 1033.33 & 976.37 \\
\hline $\begin{array}{l}\text { Garlic extract without silver nitrate125 } \\
\mu \mathrm{L} / \mathrm{L}\end{array}$ & 13.78 & 22.11 & 8.72 & 6.30 & 565.7 & 100.00 & 292.79 & 41.818 \\
\hline $\begin{array}{l}\text { Garlic extract without silver nitrate } \\
250 \mu \mathrm{L} / \mathrm{L}\end{array}$ & 19.26 & 7.72 & 7.89 & 4.26 & 830.43 & 145.07 & 255.40 & 158.18 \\
\hline $\begin{array}{l}\text { Garlic extract without Silver } \\
\text { nitrate } 500 \mu \mathrm{L} / \mathrm{L}\end{array}$ & 25.02 & 9.54 & 7.56 & 2.34 & 1108.6 & 202.85 & 496.39 & 41.81 \\
\hline Lemongrass Ag NPs $125 \mu \mathrm{L} / \mathrm{L}$ & 14.49 & 29.90 & 9.98 & 10.35 & 289.85 & 849.20 & 349.54 & 527.27 \\
\hline Lemongrass Ag NPs $250 \mu \mathrm{L} / \mathrm{L}$ & 36.18 & 26.04 & 5.38 & 13.62 & 1647.82 & 726.67 & 142.34 & 725.45 \\
\hline Lemongrass Ag NPs $500 \mu \mathrm{L} / \mathrm{L}$ & 33.43 & 22.78 & 7.34 & 14.82 & 1514.9 & 623.17 & 230.63 & 798.18 \\
\hline $\begin{array}{l}\text { Lemongrass without silver nitrate125 } \\
\mu \mathrm{L} / \mathrm{L}\end{array}$ & 8.98 & 6.3 & 4.72 & 3.57 & 356.52 & 601.90 & 112.61 & 281.81 \\
\hline $\begin{array}{l}\text { Lemongrass without silver nitrate } 250 \\
\mu \mathrm{L} / \mathrm{L}\end{array}$ & 9.45 & 22.81 & 5.74 & 4.26 & 453.14 & 624.12 & 158.55 & 158.18 \\
\hline $\begin{array}{l}\text { Lemongrass without silver nitrate500 } \\
\mu \mathrm{L} / \mathrm{L}\end{array}$ & 11.45 & 11.93 & 6.52 & 2.34 & 333.81 & 278.73 & 193.69 & 281.81 \\
\hline Maxim-XL & 46.08 & 28.95 & 23.48 & 26.7 & 2126.08 & 819.04 & 957.65 & 1618.18 \\
\hline Bio-Zeid & 38.43 & 27.37 & 23.6 & 23.04 & 1756.52 & 768.88 & 963.06 & 1296.36 \\
\hline Control 1 & 8.10 & 6.30 & 3.40 & 2.34 & 291.30 & 100 & 53.15 & 41.81 \\
\hline Control 2 & 2.07 & 3.15 & 2.22 & 1.65 & 00.00 & 0.00 & 0.00 & 0.00 \\
\hline
\end{tabular}

* Control 1: Un-inoculated soil, Control 2: Inoculated soil with FOL.

*Peroxidase activity was expressed as the increase in absorbance at $425 \mathrm{~nm} / \mathrm{gram}$ fresh weight/15 minutes.

* Polyphenoloxidase activity was expressed as the increase in absorbance at $420 \mathrm{~nm} / \mathrm{g}$ fresh weigh/ minutes.

* PAL activity was expressed as $\mu$ mol trans-cinnamic acid $\min ^{-1} \mathrm{~g}^{-1}$ protein.

* Chitinase activity was expressed as mM N-acetylglucose amine released/g fresh weight tissue/60 minutes. 
Effect of Ag NPs synthesized by plant extract on phenol content (mg/g fresh weight) in tomato plants infected with fusarium wilt (FOL) under greenhouse:

The results in Table 4 indicate that, phenol content was significantly affected by the treatment with AgNPs. Compared with control, all tested Ag NPs synthesized by plant extract increased the phenol contents. The highest increase in the total phenols was recorded with Maxim-XL (1795.80\%) followed by Neem Ag NPs $500 \mu \mathrm{L} / \mathrm{L} 1706.204 \%$. However, Neem without silver nitrate $125 \mu \mathrm{L} / \mathrm{L}$ was the least effective and increased the total phenols by 493.61\%. As for the free phenol, all tested AgNPs compounds increased the free phenols. The highest increase in the free phenols was Maxim-XL (2784.37\%) followed by Neem Ag NPs 500 $\mu \mathrm{L} / \mathrm{L}$ (2693.75\%). Neem without silver nitrate $125 \mu \mathrm{L} / \mathrm{L}$ was the least effective one. However, treatments differed in their effect on the conjugated phenols. In this respect, Neem without silver nitrate $250 \mu \mathrm{L} / \mathrm{L}$ and Neem AgNPs $125 \mu \mathrm{L} / \mathrm{L}$ decreased the conjugated phenols by 155.37 and $67.40 \%$ respectively. However, Garlic extract without silver nitrate $125 \mu \mathrm{L} / \mathrm{L}$ increased the conjugated phenols by 2007.16\%. These results agree with those of El-Refai et al., 2018 who, found that, using ginger and garlic extract for the synthesis of silver nanoparticles increased the total polyphenols, fractionation of phenols and flavonoids in treated plants.

Table 4: Effect of Ag NPs synthesized by plant extract on phenol content (mg/g fresh weight) in tomato plants infected with fusarium wilt (FOL) under greenhouse:

\begin{tabular}{|c|c|c|c|c|c|c|}
\hline \multirow{2}{*}{ Treatment } & \multirow{2}{*}{$\begin{array}{l}\text { Total } \\
\text { Phenol }\end{array}$} & \multirow{2}{*}{$\begin{array}{l}\text { Conj. } \\
\text { Phenol }\end{array}$} & \multirow{2}{*}{$\begin{array}{l}\text { Free } \\
\text { Phenol }\end{array}$} & \multicolumn{3}{|c|}{ Efficacy \% } \\
\hline & & & & $\begin{array}{l}\text { Total } \\
\text { Phenol } \\
\end{array}$ & $\begin{array}{l}\text { Conj. } \\
\text { Phenol } \\
\end{array}$ & $\begin{array}{l}\text { Free } \\
\text { Phenol } \\
\end{array}$ \\
\hline Neem Ag NPs $125 \mu \mathrm{L} / \mathrm{L}$ & 64.97 & 3.92 & 61.05 & 1085.65 & 67.40 & 1846.74 \\
\hline Neem Ag NPs $250 \mu \mathrm{L} / \mathrm{L}$ & 74.68 & 8.62 & 66.05 & 1262.71 & 267.92 & 2006.25 \\
\hline Neem Ag NPs 500 $\mu \mathrm{L} / \mathrm{L}$ & 98.98 & 11.37 & 87.61 & 1706.21 & 384.98 & 2693.75 \\
\hline Neem without silver nitrate $125 \mu \mathrm{L} / \mathrm{L}$ & 32.53 & 12.05 & 20.48 & 493.61 & 414.87 & 553.13 \\
\hline Neem without silver nitrate $250 \mu \mathrm{L} / \mathrm{L}$ & 42.83 & 5.99 & 36.84 & 681.49 & 155.38 & 1074.74 \\
\hline Neem without silver nitrate $500 \mu \mathrm{L} / \mathrm{L}$ & 52.04 & 24.41 & 27.63 & 849.59 & 943.08 & 781.25 \\
\hline Garlic Ag NPs $125 \mu \mathrm{L} / \mathrm{L}$ & 51.25 & 24.69 & 26.56 & 835.29 & 953.50 & 746.94 \\
\hline Garlic Ag NPs $250 \mu \mathrm{L} / \mathrm{L}$ & 63.11 & 35.87 & 27.24 & 1051.68 & 1430.21 & 768.75 \\
\hline Garlic Ag NPs $500 \mu \mathrm{L} / \mathrm{L}$ & 70.85 & 37.73 & 33.12 & 1192.96 & 1509.64 & 956.25 \\
\hline Garlic extract without silver nitrate125 $\mu \mathrm{L} / \mathrm{L}$ & 80.56 & 49.39 & 31.16 & 1370 & 2007.17 & 893.75 \\
\hline Garlic extract without silver nitrate $250 \mu \mathrm{L} / \mathrm{L}$ & 84.57 & 44.20 & 40.37 & 1443.25 & 1785.67 & 1187.31 \\
\hline Garlic extract without silver nitrate500 $\mu \mathrm{L} / \mathrm{L}$ & 90.45 & 29.40 & 61.05 & 1550.62 & 1154.27 & 1846.88 \\
\hline Lemongrass Ag NPs $125 \mu \mathrm{L} / \mathrm{L}$ & 74.48 & 40.96 & 33.51 & 1259.12 & 1647.61 & 968.75 \\
\hline Lemongrass Ag NPs $250 \mu \mathrm{L} / \mathrm{L}$ & 81.63 & 40.18 & 41.45 & 1389.67 & 1614.33 & 1221.75 \\
\hline Lemongrass Ag NPs $500 \mu \mathrm{L} / \mathrm{L}$ & 92.32 & 39.20 & 53.11 & 1584.59 & 1572.35 & 1593.75 \\
\hline Lemongrass without silver nitrate $125 \mu \mathrm{L} / \mathrm{L}$ & 38.22 & 16.07 & 22.14 & 597.44 & 585.67 & 606.25 \\
\hline Lemongrass without silver nitrate $250 \mu \mathrm{L} / \mathrm{L}$ & 45.67 & 13.14 & 32.53 & 733.35 & 460.49 & 937.31 \\
\hline Lemongrass without silver nitrate $500 \mu \mathrm{L} / \mathrm{L}$ & 56.64 & 15.19 & 41.45 & 933.57 & 547.87 & 1221.88 \\
\hline Maxim-XL & 103.89 & 13.44 & 90.45 & 1795.80 & 473.21 & 2784.38 \\
\hline Bio-Zeid & 85.85 & 14.99 & 70.85 & 1466.56 & 539.68 & 2159.38 \\
\hline Control 1 & 14.31 & 4.21 & 10.09 & 161.094 & 79.78 & 221.88 \\
\hline Control 2 & 5.48 & 2.34 & 3.13 & 0.00 & 0.00 & 0.00 \\
\hline
\end{tabular}

* Control 1: Un-inoculated soil, Control 2: Inoculated soil with FOL.

*Phenol contents were calculated as milligrams of catechol per one -gram fresh weight 


\section{References}

Abdel-Monaim, M. F. (2010). Induced systemic resistance in tomato plants against Fusarium wilt disease. Minia 2nd Environmental Sciences Conferences, 253-263.

Agrios, G. N. (2005). Plant Pathology. Elsevier Academic Press. San Diego, USA. 922 pp.

Allam, A. I. and Hollis, J. P. (1972). Sulfide inhibition of oxidase in rice roots. Phytopathology, 62: 634-639.

Ashraf, H.; Anjum, T.; Riaz, S. and Naseem, S. (2020). Microwave-assisted green synthesis and characterization of silver nanoparticles using Melia azedarach for the management of Fusarium wilt in tomato. Frontiers in microbiology, 11:238.

Bary, H.G. and Thorpe, W.V. (1954). Analysis of phenolic compounds of interest in metabolism // Methods of chemical analysis, 1: 27-51.

Boller, T and Mauch, F. (1988). Chitinase from Phaseolus vulguris, leaves". Meth. Enzymol, 161: 479 - 484.

Bouwmeester, H.; Dekkers, S.; Noordam, M.Y.; Werner, I. H.; Astrid, S. B.;Cees de H.; Sandra E.C.G. ten V.; Susan, W.P. W.; Hans, J.P. M. and Adriënne, J.A.M. S. (2009). Review of health safety aspects of nanotechnologies in food production', Regular Toxicol. Pharmacol., 53, pp. 52-62.

Brown, N (1924). Two mycological methods. A method of isolated single strain fungi by cutting a hyphal tip. Ann. Bot., 38: 402-406.

Dickerson, D.P., Pascholati, S.F., Hagerman, A.E., Butler, L.G. and Nicholson, R.L. (1984). Phenylalanin ammonia-lyase and hydroxy cinnamate: CoA ligase in maize mesocotyls inoculated with Helminthosporium carbonum. Physiol Plant Pathol., 25:111-123.

El- Khallal, S. M. (2007). Induction and modulation of resistance in tomato pants against Fusarium wilt disease by bio-agent fungi (Arbuscular mycorrhiza) and/or hormonal elicitors (jasmonic acid and salicylic acid):1-Changes in growth, some metabolic activities and endogenous hormones related to defense mechanism. Australian J. Basic and Appl. Sci., 1(4): 691-705.

Elamawi, R. M., and Al-Harbi, R. E. (2014). Effect of biosynthesized silver nanoparticles on Fusarium oxysporum fungus the cause of seed rot disease of faba bean, tomato and barley. J. Plant Prot. Path. Mansoura Univ., 1(12):991-1007.

El-Refai, A. A.; Ghoniem, G. A.; El-Khateeb, A. Y. and Hassaan, M. M. (2018). Ecofriendly synthesis of metal nanoparticles using ginger and garlic extracts as biocompatible novel antioxidant and antimicrobial agents. Journal of Nanostructure in Chemistry, 8(1): 7181.

FAOSTAT (2019). Global tomato production. Rome, FAO.

Gengan, R.M., Anand, K., Phulukdaree, A., Chuturgoon, A. (2013). activity of biosynthesized s ilver nanoparticles using Albizia Adianthifolia leaf. Colloids and Surfaces B: Biointerfaces 105, 87-91.

Goffeau, A. (2008). Drug resistance: the fight against fungi', Nature, 452, pp. 541-542.

Gupta, A.K. and Ganjewala, D. (2015). Synthesis of silver nanoparticles from Cymbopogon flexuosus leaves extract and their antibacterial properties. Int. J. Plant Sci. Ecol., (1): 225-230. 
Karim, Z.; Adnan, R. and Ansari, M. S. (2012). Low concentration of silver nanoparticles not only enhances the activity of horseradish peroxidase but alter the structure also. PloS one, 7(7): e41422.

Katan, T.; Zamir, D.; Sarfati, M. and Katan, J. (1991). Vegetative compatibility groups and subgroups in Fusarium oxysporum f. sp. radicis-lycopersici. Phytopathology, 81:255-262.

Madbouly, A.K.; Abdel-Aziz, M.S. and Abdel Wahhab, M.A. (2017). Biosynthesis of nanosilver using Chaetomium globosum and its application to control Fusarium wilt of tomato in the greenhouse. IET Nanobiotechnology. 11(6): 702-708.

Matei, P.M.; Beatrice, M.I.B.M.; Martín, G.J.; Pérez, L. E.; Carmen, R.M.S.; Barrio, A. M.T. and Martín, R.P. (2018). In vitro Antifungal Activity of Composites of AgNPs and Polyphenol Inclusion Compounds against Fusarium culmorum in Different Dispersion Medi. Article, Agronomy, 8, 239 1-13.

Matta, A. and Dimond, A.E. (1963). Symptoms of Fusarium wilt in relation to quantity of Fungus and enzyme activity in tomato stems. Phytopathology, 53: 574-587.

Morsy, E. M.; Abdel-Kawi, K. A. and Khalil, M. N. A. (2009). Efficiency of Trichoderma viride and Bacillus subtilis as biocontrol agents against Fusarium solani on tomato plants. Egyptian Journal of Phytopathology, 37(1): 47-57.

Nelson, P. E.; Toussoun, T. A.; Marasas, W. F. O. (1983). Fusarium species: an illustrated manual for identification. Pennsylvania State University Press, University Park.

Ozbay, N. and Newman, S. E. (2004). Effect of Trichoderma harzianum strains to colonize tomato root and improve transplant growth. Pakistan Journal of Biological Sci., 7 (2): 253-257.

Pradeep, T. (2007). Nano: the essentials-understanding nanoscience and nanotechnology. Tata McGraw-Hill, US. pp. 3-15.

Rai, M.; Yadav, A. and Gade, A .(2008). CRC 675-Current trends in phytosynthesis of metal nanoparticles. Crit Rev Biotechnol 28: 277-284.

Shankar SS, Rai A, Ahmad A, Sastry M (2004) Rapid synthesis of Au, Ag, and bimetallic Au core-Ag shell nanoparticles using Neem (Azadirachta indica) leaf broth. J Colloid Interf Sci 275(2):496-502.

Simons, T. O. and Ross, A. F. (1971). Changes in phenol metabolism associated with induced systemic resistance to tobacco mosaic virus in Sumsun NN Tobacco // Phytopathology, 61(10):1261-1265.

Song, W.; Zhou, L.; Yang, C.; Cao, X.; Zhang, L. and Liu, X., (2004). Tomato Fusarium wilt and its chemical control strategies in a hydroponic system. Crop Prot., 23: 243-247. 


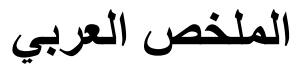

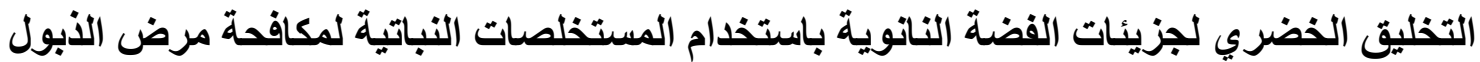

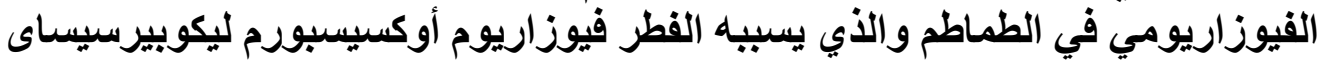

نعيمة جمعة أحمد ،عبده مهدي محمد مهاي، رؤوف نجيب فوزي، جمال عاشور أحمد

$$
\text { كلية الزراعة بمثتهر - جامعة بنها - قسم امراض النبات فوزئ }
$$

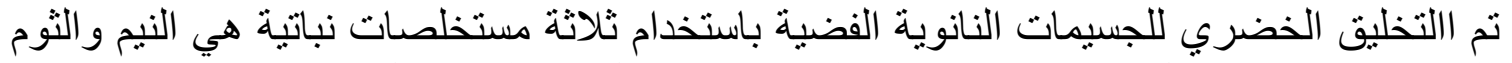

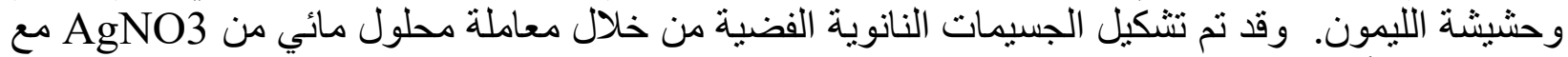

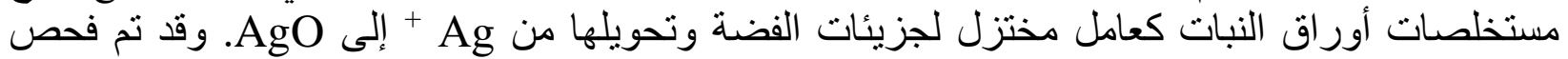

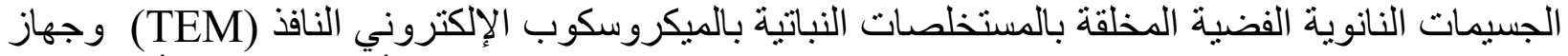

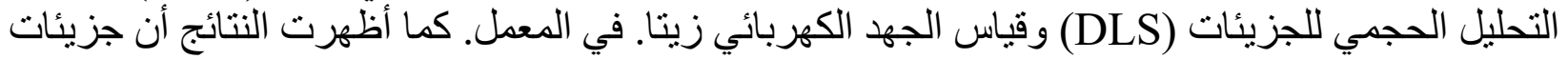

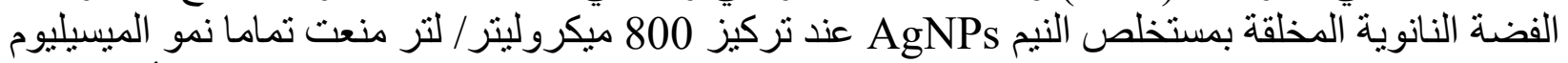

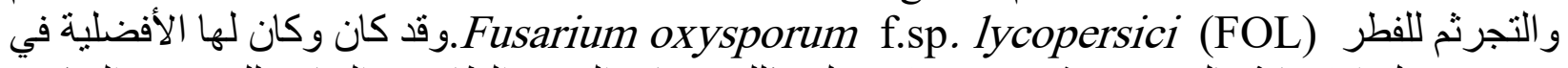

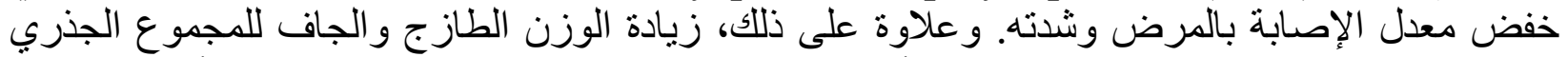

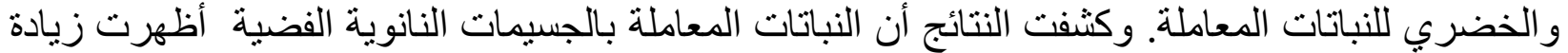

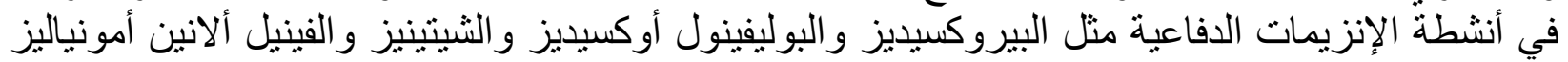

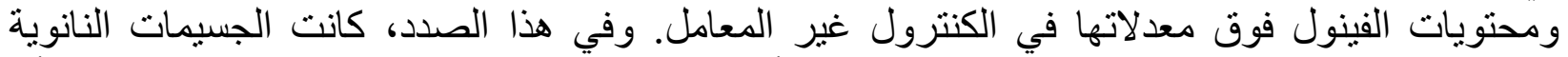

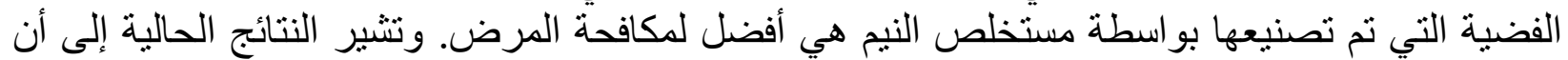

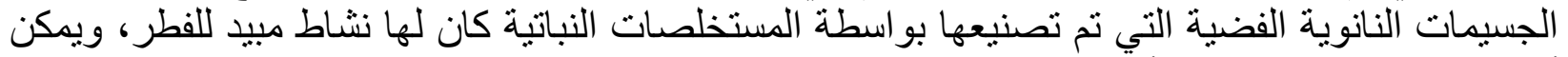
أن تكون بديلا فعالا وآمنا وبأسعار معقولة للمبيدات الفطرية الكيميائية. 